\title{
PERANCANGAN SOP MANAGEMENT REVIEW BERDASARKAN INTEGRASI ISO 9001:2015 (KLAUSUL 9.3) DAN ISO 14001:2015 (KLAUSUL 9.3) DENGAN MEMPERTIMBANGKAN RISIKO MENGGUNAKAN METODE BENCHMARK DI CV XYZ
}

\author{
${ }^{1}$ Naila Farhana, ${ }^{2}$ Sri Widaningrum, ${ }^{3}$ Heriyono Lalu \\ 1,2,3Program Studi Teknik Industri, Fakultas Rekayasa Industri, Telkom University \\ 1'farhananaila@gmail.com, ${ }^{2}$ swidaningrum@telkomuniversity.ac.id, ${ }^{3}$ heriyonolalu@telkomuniversity.ac.id
}

\begin{abstract}
Abstrak-CV XYZ merupakan perusahaan manufaktur yang telah menerapkan Sistem Manajemen Mutu (SMM) sesuai dengan ISO 9001:2008. CV XYZ memiliki beberapa SOP hasil penelitian sebelumnya, salah satunya adalah SOP management review yang telah sesuai dengan integrasi ISO 9001:2008 dan ISO 14001:2004. Perubahan standar pada ISO 9001:2015 dan ISO 14001:2015 menuntut perbaikan SOP sehingga dapat memenuhi requirement baru dan sesuai dengan kebutuhan maupun kondisi perusahaan. Berdasarkan hal tersebut dilakukan perbaikan terhadap SOP hasil penelitian sebelumnya sehingga didapatkan SOP yang memenuhi requirement standar baru. Perancangan SOP dilakukan dengan mengintegrasikan requirement ISO 9001:2015 dan ISO 14001:2015 serta menyusun proses bisnis dengan melakukan benchmark. Proses bisnis yang didapat dibandingkan dengan hasil requirement integrasi sehingga didapatkan proses bisnis sesuai dengan requirement. Berdasarkan ISO 9001:2015 dan ISO 14001:2015 mengenai penerapan risk based thinking, disusun risk register dengan menggunakan risk assessment sebagai bentuk pertimbangan risiko dalam memenuhi requirement tersebut. Penanganan risiko pada risk register menjadi masukan dalam penyusunan SOP management review. Hasil dari penelitian ini adalah SOP management review sesuai dengan requirement integrasi ISO 9001:2015 dan ISO 14001:2015 yang sudah mempertimbangkan risiko. Manfaat dari SOP hasil penelitian ini yaitu CV XYZ dapat menjamin pelaksanaan proses management review karena penyusunan prosesnya berdasarkan hasil benchmark dengan perusahaan yang telah menerapkan proses tersebut secara berkelanjutan. Berdasarkan penerapan risiko dari hasil risk register, SOP tersebut memiliki ketentuan maupun aktivitas yang dapat mengantisipasi munculnya risiko sehingga tujuan proses management review dapat tercapai.
\end{abstract}

Kata kunci: Standar Operasional Prosedur, ISO 9001:2015, ISO 14001:2015, Benchmark, Management Review

\section{PENDAHULUAN}

International Organization for Standardization (ISO) merupakan sebuah badan standardisasi internasional yang menyusun standar-standar internasional yang dapat diterapkan perusahaan. ISO mengeluarkan standar internasional yang mengatur sistem manajemen perusahaan yaitu ISO 9001 terkait sistem manajemen mutu dan ISO 14001 terkait sistem manajemen lingkungan. Perusahaan yang menerapkan standar ini diharapkan dapat menghasilkan kualitas produk sesuai dengan spesifikasi yang telah ditentukan. Hal ini disebabkan oleh pengelolaan perusahan yang sudah terjamin karena telah diatur dalam standar internasional.

CV XYZ merupakan perusahaan yang bergerak dalam bidang manufaktur dan penjualan yang telah berdiri sejak tahun 1993. Perusahaan ini telah memiliki banyak pelanggan, mitra kerja serta telah menjadi supplier beberapa perusahaan besar yang telah menerapkan ISO 9001 maupun integrasi dari ISO 9001 dan ISO 14001. Sistem manajemen mutu merupakan sebuah kesatuan antara struktur organisasi, tanggung jawab, prosedur, proses dan sumber daya yang digunakan serta saling berkaitan dalam menerapkan manajemen kualitas [1]. Sistem manajemen lingkungan membantu perusahaan untuk meminimasi efek negatif dari operasi-operasi yang memberikan dampak terhadap lingkungan [2]. Berdasarkan hal tersebut CV XYZ perlu menerapkan sistem manajemen mutu dan sistem manajemen lingkungan agar dapat terus meningkatkan kualitas produk sehingga dapat memenuhi kebutuhan serta spesifikasi dari mitra kerjanya.

Hasil penelitian yang telah dilakukan sebelumnya di CV XYZ sudah menghasilkan beberapa SOP berdasarkan requirement integrasi ISO 9001:2008 dan ISO 14001:2004 maupun integrasi standar ISO 9001:2008 dan ISO 18001:2007 [3][4][5]. Pada September 2015, ISO menerbitkan standar revisi terbaru sehingga standar ISO 9001:2008 dan ISO 14001:2004 sudah tidak lagi berlaku. Standar ISO 9001:2015 dan ISO 14001:2015 merupakan standar revisi terbaru yang harus diterapkan oleh perusahaan yang sudah menerapkan Sistem Manajemen Mutu (SMM) berdasarkan ISO 9001:2008 dan Sistem Manajemen Lingkungan (SML) berdasarkan ISO 14001:2004. Berdasarkan hal tersebut selain harus merubah SMM dan SML yang diterapkan, tuntutan dari pelanggan mengenai perubahan standar tersebut menuntut CV XYZ untuk mengubah sistem manajemen yang diterapkan sehingga dapat memenuhi requirement standar terbaru dan kebutuhan pelanggannya. Berdasarkan hal tersebut SOP hasil 
penelitian sebelumnya perlu dilakukan perbaikan sehingga dapat memenuhi requirement standar ISO 9001:2015 dan ISO 14001:2015.

Pada ISO 9001:2015 dan ISO 14001:2015 terdapat perubahan mengenai penerapan risk based thinking pada perusahaan dimana hal ini tidak dibahas dalam ISO 9001:2008 dan ISO 14001:2004 [6][7]. Maka dari itu perlu dilakukan penyempurnaan pada SOP yang ada agar dapat sesuai dengan requirement pada ISO 9001:2015 dan ISO 14001:2015 dengan melakukan pertimbangan risiko. Pertimbangan risiko yang dilakukan dalam penelitian ini adalah penyusunan risk register dengan menggunakan risk assessment. Hal ini digunakan sebagai bahan pertimbangan dalam menyusun SOP sehingga pada SOP yang telah disusun dapat mengantisipasi risiko-risiko yang muncul pada proses bisnis tersebut.

Salah satu SOP yang dihasilkan dari penelitian sebelumnya adalah SOP management review [4]. Proses management review merupakan proses yang dilakukan perusahaan dalam meninjuan sistem manajemen yang diterapkan sehingga dapat diketahui kesesuaian, kecukupan serta efektivitas dari sistem manajemen yang diterapkan [6][7]. Berdasarkan hal tersebut proses management review merupakan proses yang perlu dilaksanakan pada perusahaan agar mendapatkan kesimpulan mengenai sistem manajemen yang diterapkan serta keputusan untuk memperbaiki sistem manajemen sebagai bentuk continuous improvement.

SOP ini disusun agar dapat mengatur proses management review sehingga dapat terlaksana sesuai dengan requirement standar ISO 9001:2015 dan ISO 14001:2015. Penyusunan proses bisnis untuk CV XYZ dilakukan dengan menggunakan metode benchmark dengan perusahaan pembanding sejenis yang telah menerapkan ISO 9001:2008 dan ISO 14001:2004 serta telah melaksanakan proses management review secara berkelanjutan dan efektif. Penyusunan proses bisnis dilakukan dengan membandingkan proses pada perusahaan pembanding untuk ditentukan proses yang dapat diterapkan dan diadaptasikan. Proses benchmark merupakan proses untuk menemukan dan mengimplementasikan sesuatu yang lebih baik untuk mencapai performansi yang terbaik [8]. Penerapan dari proses bisnis perusahaan pembanding diharapkan menghasilkan proses bisnis yang sudah terbukti dapat diimplementasikan karena proses yang ada telah diterapkan pada perusahaan pembanding.

Pada proses management review yang telah diatur dalam ISO 9001:2015 dan ISO 14001:2015 terdapat beberapa kesamaan dalam persyaratannya. Persamaan ini dapat menimbulkan proses management review yang terduplikasi bila penerapan standar dilakukan secara terpisah. Sistem manajemen terintegrasi merupakan sistem yang mengkombinasikan proses, prosedur maupun instruksi kerja sehingga dalam penerapannya dapat mencapai tujuan perusahaan dengan lebih efisien bila dibandingkan dengan menggunakan berbagai macam sistem [9]. Penerapan standar secara terintegrasi dapat mengurangi terjadinya dokumen yang terduplikasi serta dapat menghasilkan sistem manejemen yang terintegrasi. Maka perlu dilakukan integrasi antara standar ISO 9001:2015 dan ISO 14001:2015 dalam penyusunan SOP Management Review CV XYZ.

Pada penelitian ini dilakukan pengintegrasian requirement standar ISO 9001:2015 (klausul 9.3) dan ISO 14001:2015 (klausul 9.3) yang digunakan dalam menyusun SOP management review sehingga dapat memenuhi requirement integrasi standar ISO 9001:2015 dan ISO 14001:2015. Penerapan risk based thinking dilakukan dalam penyusunan SOP management review untuk memenuhi requirement pada standar ISO terbaru. Penyusunan proses bisnis management review untuk CV XYZ dilakukan dengan metode benchmark untuk mendapatkan proses bisnis yang dapat diimplementasikan karena hasil perbandingan dengan perusahaan pembanding. SOP yang dihasilkan dapat menjamin pelaksanaan proses management review dan mengantisipasi risiko yang mungkin terjadi.

\section{METODE PENELITIAN}

Metode penelitian yang dilakukan pada penelitian ini digambarkan dengan model konseptual pada Gambar 1.

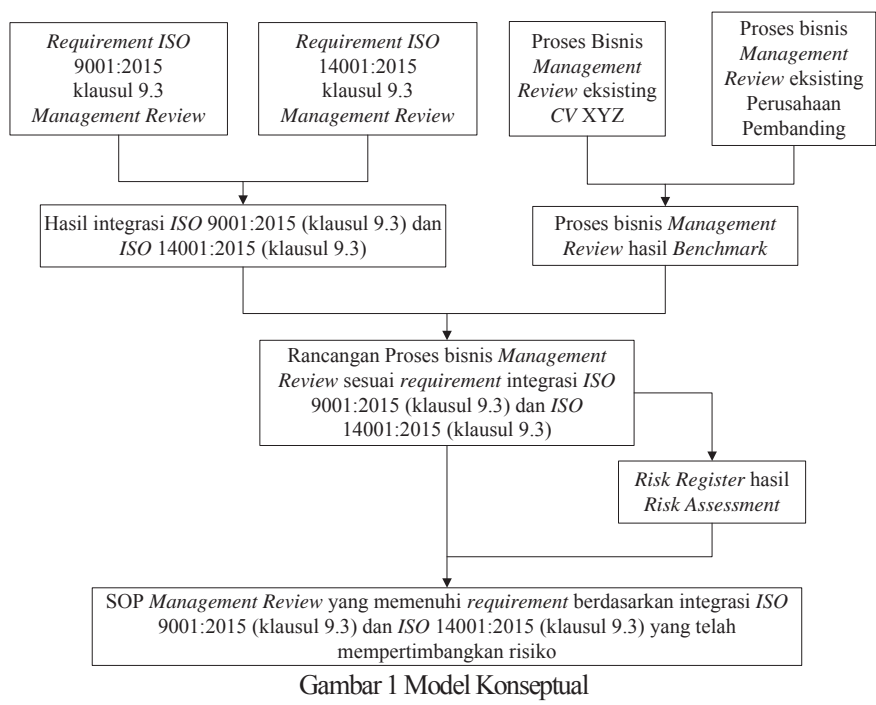

Pada model konseptual tergambarkan bahwa pada penelitian ini dilakukan integrasi requirement ISO 9001:2015 klausul 9.3 dan ISO 14001:2015 klausul 9.3 mengenai management review. Penyusunan requirement integrasi dilakukan dengan membandingkan butit-butir klausul sehingga didapatkan butir klausul yang dapat digabungkan serta butir klausul yang perlu ditambahkan. Hal ini dilakukan untuk menghasilkan requirement integrasi yang mencakup kedua standar tersebut. Selain itu dilakukan penyusunan proses bisnis management review menggunakan metode benchmark dengan membandingkan proses bisnis management review CV XYZ dan proses bisnis perusahaan pembanding. Penyusunan proses bisnis dengan metode benchmark dilakukan untuk mendapatkan aktivitas, ketentuan, atau proses yang dapat diterapkan maupun diadaptasikan oleh CV XYZ. Proses bisnis yang tersusun dilakukan perbandingan dengan requirement integrasi sehingga dihasilkan requirement yang belum terpenuhi dalam proses bisnis tersebut. Hal tersebut memberikan penambahan dalam proses bisnis yang ada sehingga didapatkan proses bisnis yang sudah memenuhi requirement integrasi ISO 9001:2015 klausul 9.3 dan ISO 14001:2015 klausul 9.3.

Proses bisnis management review yang sudah dirancang dievaluasi risiko pada proses tersebut menggunakan metode risk assessment. Metode risk assessment dilakukan dengan tiga tahap yaitu identifikasi risiko, analisis risiko, serta evaluasi risiko [10], dan diberikan penambahan dengan melakukan penanganan terhadap risiko yang didapatkan. Hasil dari risk assessment menghasilkan risk register yang mencakup rangkuman mengenai daftar risiko, hasil 
penilaian risiko terhadap dampak dan probabilitasnya, risk rating serta penanganan yang dilakukan untuk mencegah terjadinya risiko tersebut.

Penyusunan SOP dilakukan berdasarkan proses bisnis yang telah dirancang sesuai requirement integrasi dan menambahkan ketentuan maupun aktivitas berdasarkan penanganan yang terdapat pada risk register. Hal tersebut dilakukan untuk menghasilkan SOP management review yang dapat mengantisipasi terjadinya risiko yang telah teridentifikasi pada risk register. Hasil dari penelitian ini berupa SOP management review yang memenuhi requirement berdasarkan integrasi ISO 9001:2015 klausul 9.3 dan ISO 14001:2015 klausul 9.3 yang telah mempertimbangkan risiko.

\section{HASIL DAN PEMBAHASAN}

A. Requirement Integrasi ISO 9001:2015 dan ISO 14001:2015

Pada penelitian ini dihasilkan requirement integrasi standar ISO 9001:2015 klausul 9.3 dan ISO 14001:2015 klausul 9.3 mengenai management review. Requirement integrasi didapatkan dengan menggelompokkan butir-butir klausul yang serupa dan dapat digabungkan. Butir-butir klausul yang memiliki kesamaan menjadi butir klausul yang digabungkan, sedangkan butir-butir klausul yang tidak memiliki kesamaan menjadi butir klausul baru dalam requirement integrasi. Berikut ini merupakan penjabaran mengenai requirement integrasi yang dihasilkan.

\section{Klausul 9.3.1 Umum}

Top management harus memantau SMM dan SML perusahaan pada selang waktu yang telah direncanakan, untuk memastikan kesesuaian, kecukupan dan keselarasan secara berkelanjutan.

2. Klausul 9.3.2 Management Review Input

Management review harus mempertimbangkan: (1) status tindak lanjut dari management review terdahulu; (2) segala macam perubahan mengenai: isu internal dan eksternal yang berhubungan dengan SMM dan SML; kebutuhan dan ekspektasi dari pihak berkepentingan, termasuk kewajiban; kepentingan aspek lingkungan; serta risiko dan peluang; (3) informasi mengenai kinerja dan efektivitas sistem manajemen yang diterapkan, termasuk: kepuasan pelanggan dan feedback dari pihak berkepentingan lainnya yang relevan; tingkat pemenuhan sasaran manajemen mutu serta manajemen lingkungan perusahaan; kinerja proses dan kesesuaian produk maupun jasa; ketidaksesuaian dan tindakan korektif; hasil pemantauan dan pengukuran; pemenuhan kewajiban; hasil audit; serta kinerja provider eksternal; (4) kecukupan sumber daya; (5) efektivitas tindakan yang diambil untuk risiko dan peluang; (6) komunikasi yang relevan dari pihak berkepentingan termasuk keluhan; serta (7) peluang untuk perbaikan.

\section{Klausul 9.3.3 Management Review Outputs}

Hasil dari management review harus mencakup: (1) kesimpulan dari kesesuaian, kecukupan dan keselarasan SML; (2) keputusan mengenai peluang untuk perbaikan; (3) kebutuhan untuk merubah SMM atau SML; (4) kebutuhan sumber daya; (5) tindak lanjut yang dilakukan bila tujuan SML belum tercapai; (6) peluang untuk mengintegrasikan SML dengan proses bisnis lainnya, bila diperlukan; serta (7) implikasi untuk arahan strategis perusahaan. Organisasi harus memelihara informasi terdokumentasi sebagai bukti dari hasil management review.
Hasil requirement integrasi menjadi requirement yang harus dipenuhi dalam menyusun SOP management review. Penyusunan proses bisnis management review harus disesuaikan sehingga dapat memenuhi seluruh requirement integrasi yang dihasilkan. Proses bisnis yang diatur dalam SOP merupakan proses bisnis yang telah memenuhi requirement integrasi ISO 9001:2015 klausul 9.3 dan ISO 14001:2015 klausul 9.3.

\section{B. Proses Bisnis Sesuai Requirement Integrasi}

Proses bisnis hasil benchmark dengan proses bisnis perusahaan pembanding dibandingkan dengan requirement integrasi untuk mendapatkan proses bisnis yang telah memenuhi requirement integrasi tersebut. Proses bisnis dibandingkan dengan requirement integrasi yang telah dihasilkan untuk menentukan aktivitas yang tersusun sudah memenuhi requirement integrasi. Penambahan pada aktivitas maupun ketentuan merupakan bentuk penambahan untuk memenuhi requirement yang belum terpenuhi sehingga didapatkan proses bisnis yang telah sesuai dengan requirement integrasi. Tabel I menunjukkan proses bisnis management review yang telah sesuai dengan requirement integrasi.

TABEL I

PROSES BISNIS SESUAI REQUIREMENT INTEGRASI

\begin{tabular}{|c|c|}
\hline No. & Aktivitas \\
\hline 1 & $\begin{array}{l}\text { Merencanakan jadwal dan tempat rapat tinjauan manajemen yang } \\
\text { dicatat dalam formulir. }\end{array}$ \\
\hline 2 & $\begin{array}{l}\text { Mengidentifikasi materi tinjauan manajemen dan mendistribusikan } \\
\text { kepada peserta tinjauan manajemen. }\end{array}$ \\
\hline 3 & $\begin{array}{l}\text { Membuat dan mendistribusikan surat undangan rapat kepada peserta } \\
\text { tinjauan manajemen. }\end{array}$ \\
\hline 4 & $\begin{array}{l}\text { Membahas serta menetapkan status tindak lanjut tinjauan } \\
\text { manajemen sebelumnya. }\end{array}$ \\
\hline 5 & Membahas bahasan tinjauan manajemen. \\
\hline 6 & Memberikan penyelesaian sesuai dengan sasaran perusahaan \\
\hline 7 & $\begin{array}{l}\text { Mencatat notulen rapat tinjauan manajemen dan tindak lanjut yang } \\
\text { disepakati pada form. }\end{array}$ \\
\hline 8 & $\begin{array}{l}\text { Membacakan notulen rapat dan tindak lanjut tinjauan manajemen } \\
\text { yang telah dihasilkan. }\end{array}$ \\
\hline 9 & Mendistribusikan notulen rapat tinjauan manajemen. \\
\hline 10 & Menyimpan notulen rapat tinjauan manajemen. \\
\hline 11 & $\begin{array}{l}\text { Memonitor dan melaporkan status penyelesaian tindak lanjut pada } \\
\text { tinjauan manajemen berikutnya. }\end{array}$ \\
\hline
\end{tabular}

Bahasan tinjauan manajemen yang dibahas dalam proses yang telah dirancang diatur dalam materi tinjauan manajemen sesuai dengan requirement standar ISO 9001:2015 (klausul 9.3) dan ISO 14001:2015 (klausul 9.3). Tabel II menunjukkan materi tinjauan manajemen yang dibahas dalam proses managamenet review hasil rancangan. 
Pada proses management review yang disusun terdapat keluaran minimal yang harus dihasilkan pada proses tersebut. Keluaran minimal dari proses management revirew meliputi perbaikan pada keefektifan SMM dan SML, serta proses-prosesnya; perbaikan produk berkaitan dengan persyaratan pelanggan; serta penyediaan sumber daya yang diperlukan.

TABEL II

MATERI TINJAUAN MANAJEMEN SESUAI REQUIREMENT INTEGRASI

\begin{tabular}{|c|c|}
\hline No. & Materi Bahasan \\
\hline 1 & Hasil tinjauan manajemen yang lalu dan tindak lanjut \\
\hline 2 & $\begin{array}{l}\text { Status tindakan perbaikan dan pencegahan dalam rangka proses } \\
\text { penerapan SMM dan SML dengan mempertimbangkan isu internal } \\
\text { dan eksternal yang berhubungan dengan SMM dan SML }\end{array}$ \\
\hline 3 & $\begin{array}{l}\text { Status dan tindak lanjut pencapaian kinerja perusahaan yang } \\
\text { berkaitan dengan SMM dan SML dengan mempertimbangkan } \\
\text { analisis operasional }\end{array}$ \\
\hline 4 & $\begin{array}{l}\text { Status dan tindak lanjut tingkat pemenuhan tujuan dan sasaran serta } \\
\text { usulan sumber daya untuk mencapai sasaran dan tujuan manajemen } \\
\text { mutu dan lingkungan dengan mempertimbangkan analisis sasaran } \\
\text { mutu dan lingkungan }\end{array}$ \\
\hline 5 & $\begin{array}{l}\text { Status dan tindak lanjut terhadap komunikasi dari pihak eksternal } \\
\text { termasuk keluhan masyarakat dan pelanggan yang berkaitan dengan } \\
\text { mutu dan lingkungan dengan mempertimbangkan analisis umpan } \\
\text { balik dan survey kepuasan pelanggan }\end{array}$ \\
\hline 6 & Status kinerja provider eksternal \\
\hline 7 & $\begin{array}{l}\text { Status dan tindak lanjut mengenai hasil audit internal dan eksternal } \\
\text { dari SMM dan SML dengan mempertimbangkan analisis hasil audit }\end{array}$ \\
\hline 8 & $\begin{array}{l}\text { Perubahan/perkembangan persyaratan hukum dan persyaratan } \\
\text { lainnya termasuk aspek lingkungan dan evaluasi ketaatan, kepatuhan } \\
\text { terhadap peraturan dan persyaratan dalam rangka penerapan SMM } \\
\text { dan SML }\end{array}$ \\
\hline 9 & $\begin{array}{l}\text { Efektivitas tindakan yang diambil untuk risiko dan peluang serta } \\
\text { perubahannya }\end{array}$ \\
\hline 10 & $\begin{array}{l}\text { Rekomendasi perbaikan kemungkinan perubahan kebijakan mutu, } \\
\text { lingkungan, serta elemen/klausul lain yang terkait dalam penerapan } \\
\text { SMM dan SML }\end{array}$ \\
\hline
\end{tabular}

\section{Hasil Risk Assessment}

Risk assessment dilakukan dalam tiga tahapan yaitu identifikasi risiko, analisis risiko dan evaluasi risiko [10] serta dilakukan penanganan terhadap risiko yang didapatkan. Risk assessment dilakukan pada proses bisnis management review yang sudah sesuai dengan requirement integrasi. Pada risk assessment dilakukan identifikasi risiko dengan menentukan bahaya dari setiap aktivitas dalam proses management review untuk didapatkan risiko yang mungkin muncul. Hasil dari identifikasi risiko menghasilkan daftar risiko dari proses management review. Risiko yang terdaftar kemudian diberikan kodefikasi sehingga memudahkan dalam pengolahan data berikutnya. Kodefikasi yang diberikan disesuaikan dengan ketentuan pada Prosedur Pengendalian Informasi Terdokumentasi yang disusun berbarengan dengan penelitian yang sedang dilakukan. Daftar risiko yang didapatkan kemudian diberikan penilaian terhadap dampak serta probabilitas terjadinya risiko tersebut pada tahap analisis risiko. Tahap analisis risiko dilakukan untuk memahami lebih dalam mengenai risiko-risiko yang telah teridentifikasi pada tahap identifikasi risiko [10]. Pengukuran risiko terhadap besar dampak serta probabilitas terjadinya sebuah risiko diterjemahkan dalam skala numerik sebagai alat ukur agar mempermudah dalam mengevaluasi risiko. Tabel III menunjukkan skala probabilitas yang digunakan dalam mengukur probabilitas terjadinya risiko yang teridentifikasi [11]. Probabilitas terjadinya risiko pada Tabel III menyesuaikan terhadap pelaksanaan proses management review yang diterjemahkan menjadi skala numerik untuk memudahkan dalam pengukuran.

TABEL III

SKALA PROBABILITAS

\begin{tabular}{|c|c|c|}
\hline \\
\hline Likelihood & Probabilitas Terjadinya Risiko & $\begin{array}{c}\text { Skala } \\
\text { Numerik }\end{array}$ \\
\hline $\begin{array}{l}\text { Almost } \\
\text { Certain }\end{array}$ & $\begin{array}{l}\text { Probabilitas terjadinya risiko lebih dari } 90 \% \text {, } \\
\text { sering terjadi setiap pelaksanaannya }\end{array}$ & 5 \\
\hline Likely & $\begin{array}{l}\text { Probabilitas terjadinya risiko antara } 50 \%-90 \% \text {, } \\
\text { serting terjadi satu kali dalam dua tahun pada } \\
\text { pelaksanaannya }\end{array}$ & 4 \\
\hline Possible & $\begin{array}{l}\text { Probabilitas terjadinya risiko antara } 10 \%-50 \% \text {, } \\
\text { kemungkinan terjadi dua kali dalam } 5 \text { tahun pada } \\
\text { pelaksanaannya }\end{array}$ & 3 \\
\hline Unlikely & $\begin{array}{l}\text { Probabilitas terjadinya risiko antara } 5 \%-10 \% \text {, } \\
\text { mungkin terjadi sekali dalam } 5 \text { tahun pada } \\
\text { pelaksanaannya }\end{array}$ & 2 \\
\hline Rare & $\begin{array}{l}\text { Probabilitas terjadinya risiko kurang dari } 5 \% \text {, } \\
\text { hampir tidak pernah terjadi } \\
\text { terakhir dalam pelaksana } 5 \text { tahun } \\
\text { tannya }\end{array}$ & 1 \\
\hline
\end{tabular}

Tabel IV menunjukkan skala dampak yang digunakan dalam mengukur besar dampak risiko yang telah teridentifikasi pada proses managamenet review [11].

TABEL IV

SKALADAMPAK

\begin{tabular}{|c|l|c|}
\hline Dampak & \multicolumn{1}{|c|}{ SKALADAMPAK } & $\begin{array}{c}\text { Skala } \\
\text { Numerik }\end{array}$ \\
\hline Catastrophic & $\begin{array}{l}\text { Deskripsi } \\
\text { dampak yeristiwa atau keadaan dengan potensi } \\
\text { materi yang dapat menghentikan bisnis } \\
\text { perusahaan dan tujuan bisnis yang tidak tercapai }\end{array}$ & 5 \\
\hline Major & $\begin{array}{l}\text { Peristiwa atau keadaan yang dapat memberikan } \\
\text { dampak materi pada bisnis perusahahan dan key } \\
\text { business objective yang tidak tercapai }\end{array}$ & 4 \\
\hline Moderate & $\begin{array}{l}\text { Peristiwa atau keadaan yang memberikan dampak } \\
\text { yang terlihat dan beberapa tujuan bisnis tidak } \\
\text { tercapai }\end{array}$ & 3 \\
\hline Minor & $\begin{array}{l}\text { Peristiwa atau keadaan yang dapat memberikan } \\
\text { beberapa dampak yang mudah untuk diperbaiki }\end{array}$ & 2 \\
\hline Insignificant & $\begin{array}{l}\text { Peristiwa atau keadaan dimana memberikan } \\
\text { dampak yang tidak terlihat }\end{array}$ & 1 \\
\hline
\end{tabular}

Hasil pengukuran pada analisis risiko kemudia dievaluasi pada tahap evaluasi risiko. Evaluasi risiko dilakukan dengan menentukan risk rating setiap risiko yang teridentifikasi berdasarkan dampak dan probabilitas yang disusun dalam matrik risiko. Gambar 2 
menunjukkan matrik risiko yang digunakan dalam menentukan rating dari masing-masing risiko yang teridentifikasi [11].

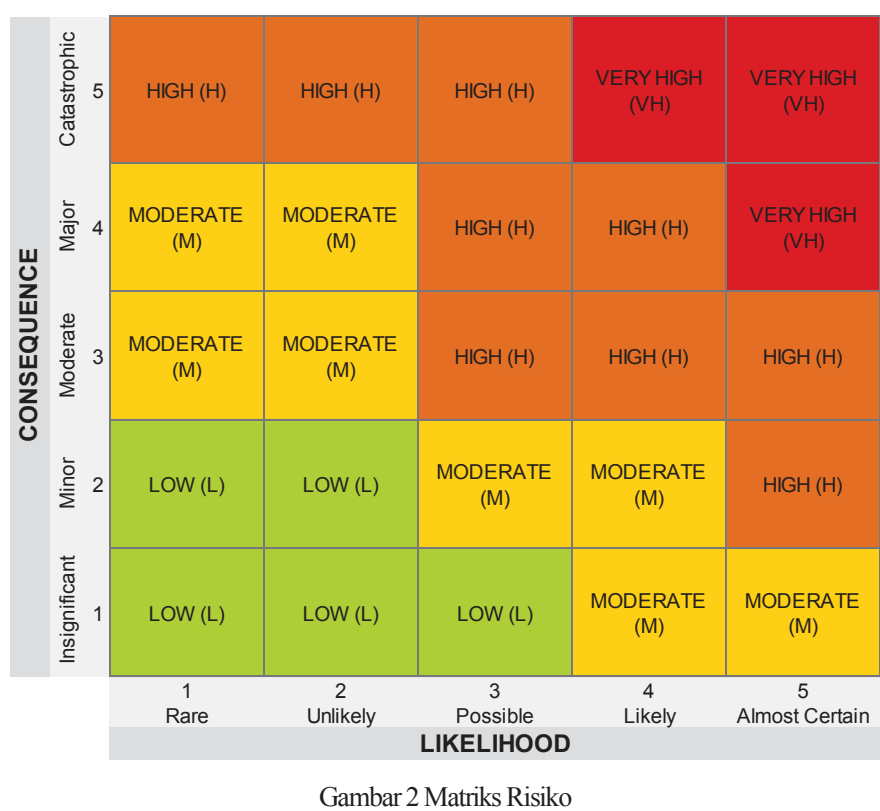
[12].

Hasil evaluasi risiko menghasilkan rating risk sebagai berikut

a. Risiko very high (sangat tinggi) atau high (tinggi) merupakan risiko yang memerlukan perhatian serta penanganan yang segera.

b. Risiko moderate (sedang) merupakan risiko yang penanganannya tidak harus sesegera risiko very high atau risiko high namun diperlukan pemantauan khusus dalam penanganannya.

c. Risiko low (rendah) merupakan risiko yang penanganan cukup dengan menggunakan prosedur rutin dan tidak memerlukan sumber daya yang spesifik.

Risiko yang telah ditentukan risk rating dibagi berdasarkan penanganan yang harus dilakukan. Risiko dengan rating very high dan high dilakukan penanganan pada tahap penanganan risiko sedangkan untuk risiko moderate dan low merupakan risiko yang ditoleransi atau diterima risikonya. Berdasarkan hal tersebut risiko dengan rating very high dan high merupakan risiko yang dilakukan penanganan. Penanganan diberikan dengan menentukan akar penyebab risiko tersebut sehingga penanganan yang didapatkan dapat efektif dalam mencegah dan mengantisipasi risiko tersebut.

Tabel V menunjukkan tabel hasil risk assessment dimana hasil identifikasi risiko, analisis risiko, evaluasi risiko serta penanganan risiko dirangkung dalam satu dokumen. Risk register menghasilkan kesimpulan mengenai risiko yang memiliki rating high beserta hasil penilaian terhadap dampak dan probabilitasnya serta program penanganan untuk mencegah risiko tersebut.

Program penanganan yang dihasilkan pada risk assessment menjadi masukan dalam penyusunan SOP. Masukan dapat berupa aktivitas maupun ketentuan baru sebagai bentuk pencengahan dalam menghindari dan mengantisipasi risiko.

\section{Rancangan SOP Management Review}

Hasil dari penelitian ini adalah SOP management review yang telah memenuhi requirement integrasi ISO 9001:2015 klausul 9.3 dan ISO 14001:2015 klausul 9.3. SOP yang dihasilkan pun dapat mengantisipasi risiko yang mungkin terjadi karena telah mempertimbangkan penanganan risiko dalam menyusun SOP management review. Hasil rancangan SOP merupakan SOP yang telah diverifikasi oleh perusahaan dimana hal ini menunjukkan bahwa SOP yang dihasilkan memiliki aktivitas yang dapat diimplementasikan oleh pihak perusahaan serta memiliki keandalan SOP yang cukup tinggi karena kemudahan SOP tersebut untuk dipahami oleh pelaku proses. Prosedur hasil rancangan yang diatur dalam SOP management review dilampirkan pada Lampiran.

Pada requirement integrasi terdapat ketentuan mengenai penentuan pelaksanaan proses management review sehingga top management dapat memastikan keberlangsungan SMM maupun SML perusahaan. Requirement tersebut telah dipenuhi dalam SOP yang telah dirancang yaitu dalam penentuan pelaksanaan Rapat Tinjauan Manajemen (RTM). Requirement lain mengenai masukanmasukan yang perlu dipertimbangkan dalam proses management review telah dipenuhi dengan penentuan bahasan materi tinjauan manajemen. Materi tinjauan manajemen yang dibahas dalam RTM telah mempertimbangkan masukan-masukan yang terdapat pada requirement integrasi. Penentuan keluaran minimal yang diatur dalam RTM telah memenuhi requirement integrasi mengenai keluaran yang harus dihasilkan pada proses management review. Requirement mengenai kewajiban dalam memelihara informasi terdokumentasi sebagai bukti pelaksanaan proses management review telah dipenuhi dengan adanya aktivitas menyimpan notulen rapat tinjauan manajemen serta tindak lanjut yang disepakati sesuai dengan ketentuan pada Prosedur Pengendalian Informasi Terdokumentasi yang disusun berbarengan dengan penelitian ini.

Hasil rancangan telah sesuai dengan kondisi perusahaan karena didukung dengan rekomendasi penambahan fungsi pada struktur organisasi CV XYZ dimana terdapat fungsi wakil manajemen yang terdiri dari tiga bagian yaitu bagian pengendali mutu dan lingkungan, bagian audit, dan bagian pengendali informasi terdokumentasi. Fungsi baru ini disusun untuk mendukung proses management review sehingga dapat terlaksana di CV XYZ.

Pada SOP yang dirancang sudah dapat menjamin terlaksananya proses management review dengan adanya penentuan dalam pelaksanaan rapat tinjauan manajemen yang disesuaikan dengan pelaksanaan audit internal sehingga pembahasan mengenai audit dapat terlaksana dan tujuan dari rapat tinjauan manajemen dapat tercapai. Pada SOP yang dihasilkan sudah mempertimbangkan informasi yang diberikan dari proses analisis dan evaluasi dengan adanya aktivitas menerima laporan hasil analisis dan evaluasi. Hal tersebut menunjukkan bahwa SOP yang disusun sudah mempertimbangkan proses-proses terkait sehingga tidak terdapat kesenjangan dalam perpindahan informasi antar proses yang diatur dalam SOP. 
TABEL V

HASIL RISK ASSESSMENT

\begin{tabular}{|c|l|l|c|c|c|c|c|}
\hline No. & $\begin{array}{c}\text { Kode } \\
\text { Risiko }\end{array}$ & \multicolumn{1}{|c|}{ Risiko } & $L$ & $S$ & $R$ & $\begin{array}{l}\text { Penanggung } \\
\text { Jawab }\end{array}$ \\
\hline 1 & TMR5G & $\begin{array}{l}\text { Tidak ada tindakan } \\
\text { pencegahan dan perbaikan } \\
\text { terhadap temuan yang } \\
\text { didapatkan }\end{array}$ & 3 & 3 & $H$ & $\begin{array}{l}\text { Melakukan mitigasi: } \\
\text { 1. Melakukan pengecekan pada materi yang telah ditentukan } \\
\text { 2. Mengecek laporan hasil analisis yang dilaporkan kepada wakil } \\
\text { manajemen menggunakan checklist. }\end{array}$ \\
\hline 2 & TMR7A & $\begin{array}{l}\text { Terdapat bahasan yang } \\
\text { terlewat pada notulen tinjauan } \\
\text { manajemen dan tindak lanjut } \\
\text { yang telah dihasilkan }\end{array}$ & 3 & 3 & $H$ & $\begin{array}{l}\text { Melakukan mitigasi: } \\
\text { 1. Melakukan pencatatan selama rapat berlangsung, tidak } \\
\text { dilakukan diakhir dan dibantu dengan alat rekam untuk mevalidasi } \\
\text { notulen yang dihasilkan } \\
\text { 2. Menyusun form yang mudah untuk diisi dan dipahami }\end{array}$ \\
\hline
\end{tabular}

Keterangan : $L=$ Likelihood, $S=$ Severity, $R=$ Rating, $H=$ High

\section{KESIIMPULAN}

Pada penelitian yang dilakukan terdapat beberapa keluaran yang dihasilkan berupa requirement integrasi, risk register, serta SOP management review.

Requirement integrasi yang dihasilkan merupakan hasil integrasi antara ISO 9001:2015 klausul 9.3 dan ISO 14001:2015 klausul 9.3. Requirement integrasi yang dihasilkan mencakup ketentuan dalam melaksanakan proses management review dalam selang waktu yang telah terencana untuk memastikan kesesuaian, kecukupan serta keefektifan sistem manajemen yang diterapkan perusahaan. Requirement integrasi pun mengatur masukan yang harus dipertimbangkan serta keluaran yang harus dihasilkan dari proses management review. Requirement lain yang diatur dalam requirement integrasi yaitu untuk memelihara informasi terdokumentasi yang dihasilkan dari proses management review sebagai bentuk pelaksanaan proses tersebut.

Hasil dari penelitian ini berupa risk register untuk proses management review. Pada risk register yang dihasilkan terdapat dua risiko yang termasuk dalam kategori high yaitu risiko mengenai tidak ada tindakan pencegahan dan perbaikan terhadap temuan yang didapatkan (R-MRV-013) dan risiko mengenai terdapat bahasan yang terlewat pada notulen tinjauan manajemen dan tindak lanjut yang telah dihasilkan (R-MRV-019). Penanganan yang diberikan untuk mengantisipasi risiko-risiko tersebut yaitu dengan melakukan pengecekan pada materi yang telah ditentukan dengan bahasan yang telah dibahas, mengecek laporan hasil analisis yang dilaporkan, melakukan pencatatan selama rapat berlangsung dibantu dengan alat rekam, serta menyusun form yang mudah untuk diisi dan dipahami.

Hasil dari penelitian ini berupa SOP management review yang disusun berdasarkan proses bisnis yang telah sesuai dengan requirement integrasi serta pertimbangan risiko berdasarkan risk register. SOP management review yang dihasilkan telah sesuai dengan requirement integrasi dan dapat mengantisipasi risiko yang mungkin menghambat proses management review dalam mencapai tujuannya.

\section{DAFTAR PUSTAKA}

[1] Gaspersz, Vincent. 2013. All-in-one Bundle of ISO 9001, ISO 14001, OHSAS 18001, ISO 22000, ISO 26000, ISO 28000, ISO 31000, ISO 13053-1, ISO 19011 and Continual Improvement. Bogor: Tri-Al-Bros Publishing.

[2] Tricker, Ray. 2010. ISO 9001:2008 for Small Businesses (Fourth Edition). London: Elsevier.

[3] Khalidah, Hana. 2014. Perancangan Standar Operasional Prosedur (SOP) dan Kebijakan Lingkungan Untuk Memenuhi Requirement ISO Berdasarkan Integrasi ISO 9001:2008 dan ISO 14001:2004 (Klausul 4.1, 4.2, 4.3.1, 4.3.2, 4.3.3, 4.4.1, 4.4.2, 4.4.4, 4.5.2, 4.5.3) di CV Gradient dengan Metode Business Process Improvement.

[4] Fatharani, Hasna. 2014. Perancangan Standar Operasional Prosedur (SOP) untuk Memenuhi Requirement ISO Berdasarkan Integrasi ISO 9001:2008 dan ISO 14001:2004 (Klausul 4.4.3, 4.4.5, 4.4.6, 4.4.7, 4.5.1, 4.5.4, 4.5.5, 4.6) di CV Gradient Dengan Metode Business Process Improvement.

[5] Talcha, Fadhila. 2014. Perancangan Standar Operasional Prosedur untuk Memenuhi Requirement Integrasi ISO 9001:2008 dengan OHSAS 18001:2007 (Klausul 4.4.5, 4.4.6, 4.4.7, 4.5.4, dan 4.5.5) di CV Gradient Menggunakan Metode Business Process Improvement.

[6] ISO. 2015. ISO 14001:2015 Environmental Management System - Requirement with Guidance for Use. Swiss: ISO.

[7] ISO. 2015. ISO 9001:2015 Quality Management System Requirement. Swiss: ISO.

[8] DeToro, I dan A Tenner. 1997. Process Redesign. Canada: Addison Wesley Longman, Inc.

[9] Akpolat, Hasan dan Jichao Xu, Integrated Management SystemQuality, Environment and Safety, Asian Journal on Quality, Volume 3 Iss 1, 2002, pp. 85 - 90.

[10]ISO. 2009. ISO 31000:2009 Risk Management - Principles and Guidelines on Implementation. Swiss: ISO.

[11]https://survey.charteredaccountants.com.au/risk_managem ent/default.aspx, diakses Maret 2016.

[12]Susilo, Leo J dan Victor Riwu Kaho. 2014. Panduan Manajemen Risiko Berbasis ISO 31000 Industri NonPerbankan. Jakarta: PPM. 


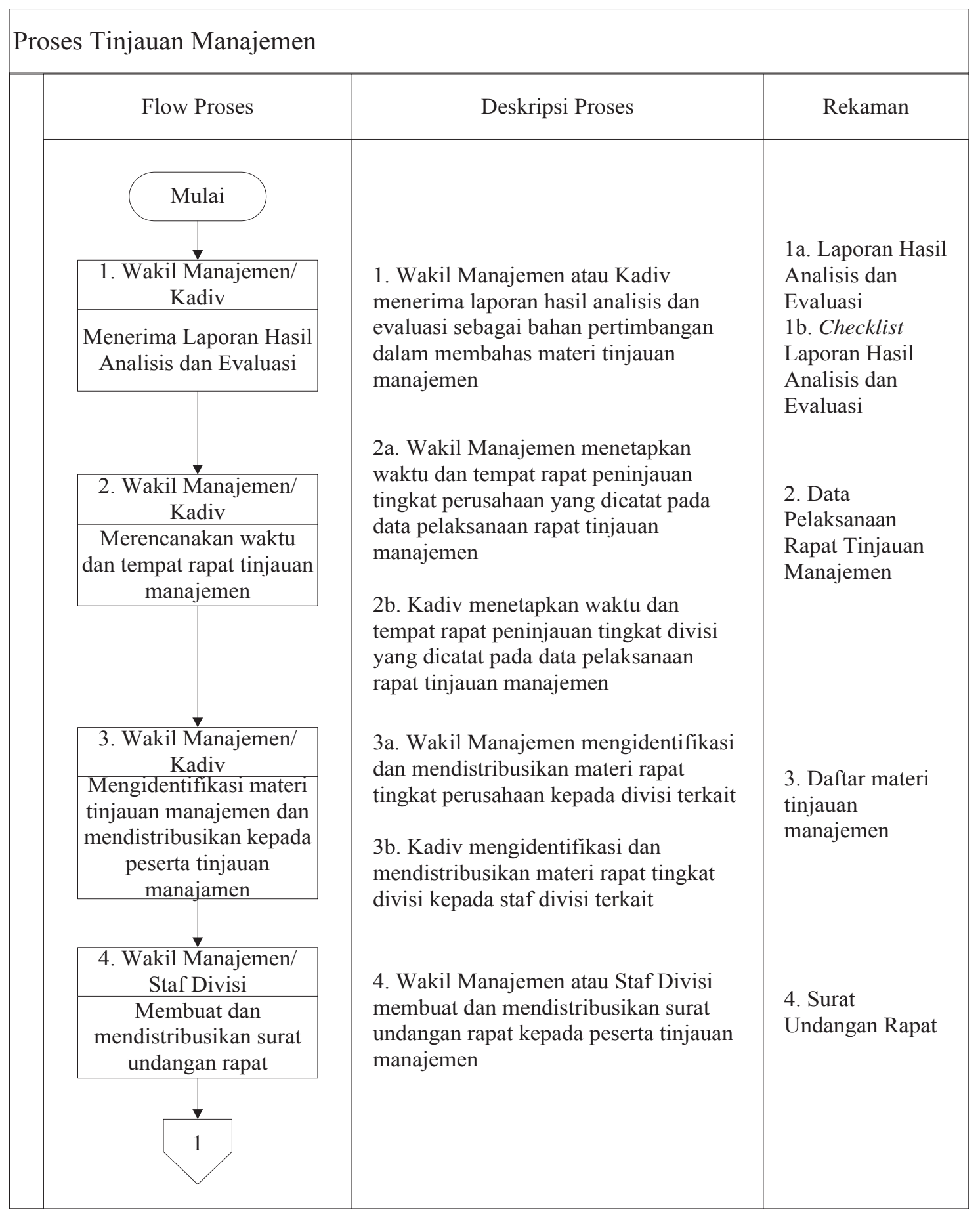




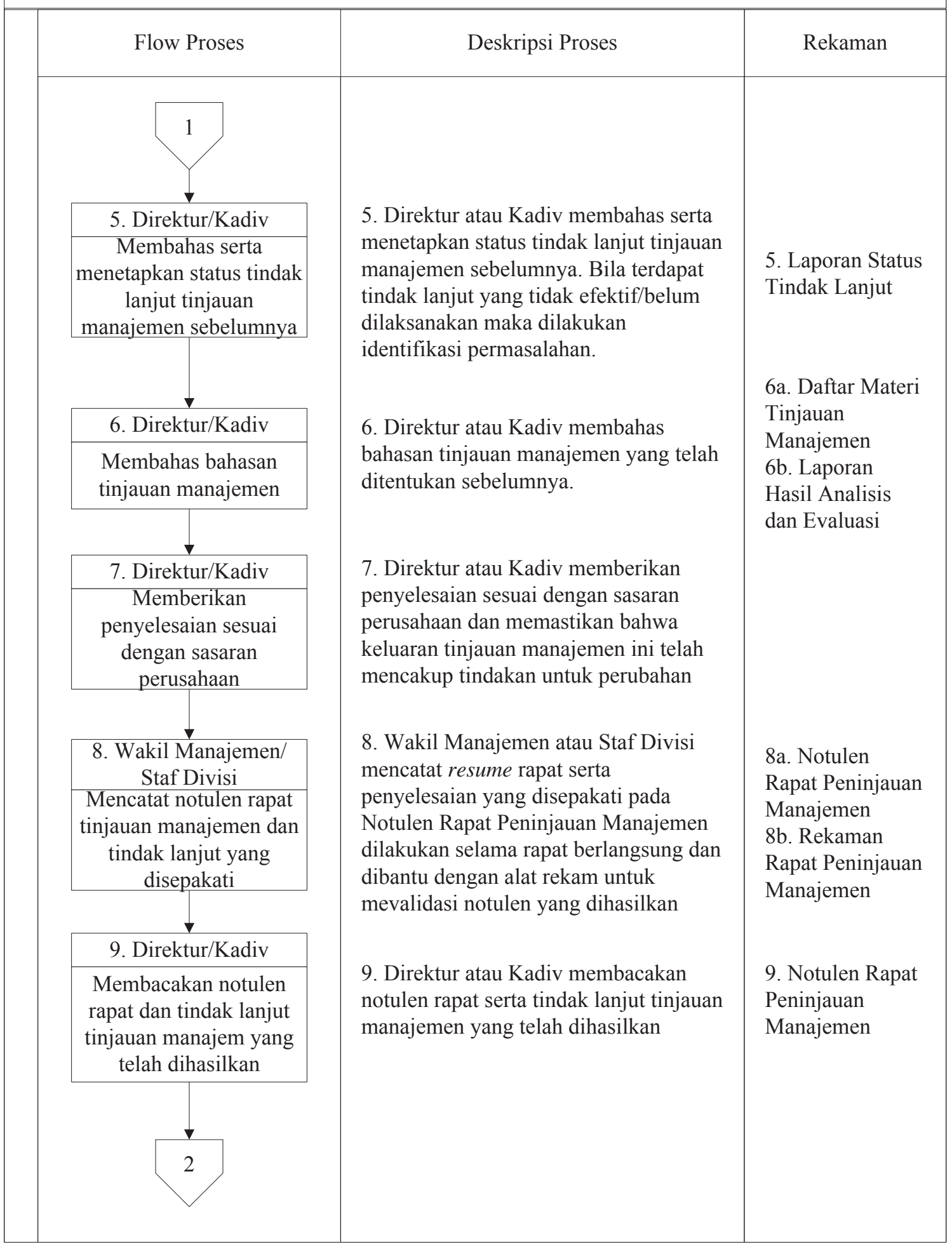




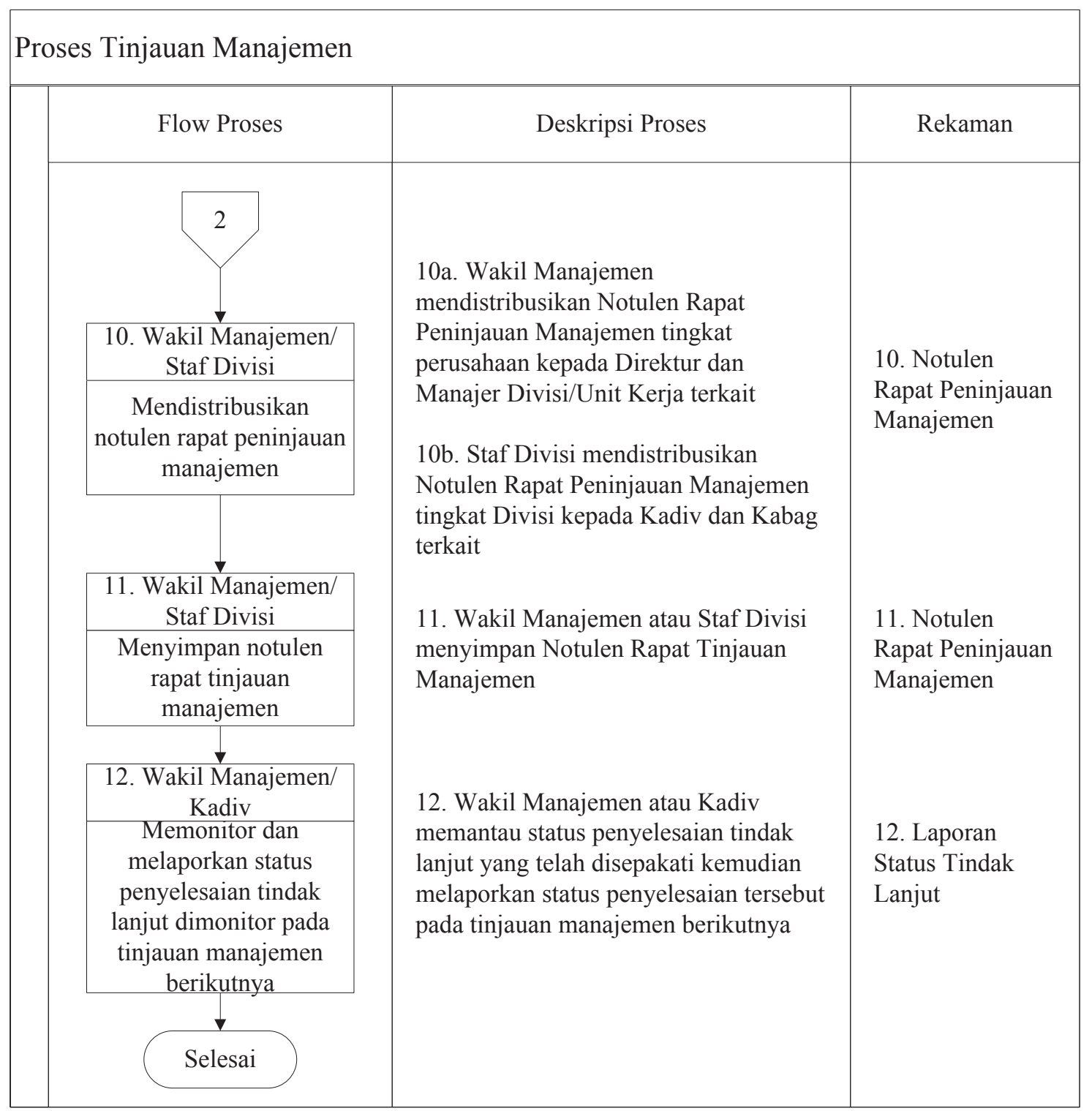

